\title{
ANALISIS KOMPARASI ATAS KINERJA DAN KEUANGAN BADAN LAYANAN UMUM BIDANG PENYEDIAAN JASA PENDIDIKAN
}

\author{
Yuliana Sari $^{1}$, Nelly Masnila ${ }^{2}$, Endah Widyastuti $^{3}$, Riza Wahyudi ${ }^{4}$ \\ 1,2,3,4 Jurusan Akuntansi, Politeknik Negeri Sriwijaya \\ ${ }^{2}$ correspondence Author \\ nellymasnila@gmail.com;
}

\begin{abstract}
In its implementation, currently, efforts to provide services to the public are not optimal yet. This research is focused on BLU which provides educational service provision services, consisting of 33 state universities throughout Indonesia under the Ministry of Research, Technology and Education. The purpose of this study is to determine the development of performance and the development of financial position. From the results, it can be concluded that the performance and financial conditions of the BLU of higher education institutions in Indonesia continue to increase throughout the period 2013-2016. In addition, there are differences in performance between universities, which can be seen from the obtained surplus or deficit experienced by certain universities. This difference is suspected because between universities have a wide range of activities and different of how to manage it.
\end{abstract}

Keywords: performance, financial position, Public Service Agency, education

\begin{abstract}
Abstrak
Badan Layanan Umum (BLU) adalah instansi di lingkungan pemerintah yang dibentuk untuk memberikan pelayanan kepada masyarakat berupa penyediaan barang dan/atau jasa yang dijual tanpa mengutamakan mencari keuntungan dan dalam melakukan kegiatannya didasarkan pada prinsip efisiensi dan produktivitas. Tujuan dibentuknya organisasi penyelenggara pelayanan publik menjadi Badan Layanan Umum (BLU) adalah peningkatan kinerja pelayanan publik menjadi lebih baik. Perubahan status menjadi BLU diharapkan dapat memperbaiki kinerja penyelenggara pelayanan publik, khususnya dalam hal pengelolaan keuangan. Dalam pelaksanaannya, upaya peningkatan layanan kepada masyarakat saat ini masih belum optimal. Beberapa hasil penelitian terkait aktivitas/kinerja dan posisi keuangan BLU pada umumnya dilakukan pada satu unit (BLU) tunggal dan pada waktu yang berbeda serta menunjukkan hasil yang relative berbeda pula satu sama lain. Penelitian ini difokuskan pada BLU yang memberikan layanan penyediaan jasa pendidikan, terdiri dari 33 satuan kerja. Dari hasil penelitian di atas dapat disimpulkan bahwa:1) Kinerja keuangan BLU perguruan tinggi yang ada di Indonesia pada periode 2013-2016 terus mengalami peningkatan; 2) Kondisi keuangan BLU perguruan tinggi yang ada di Indonesia juga terus mengalami peningkatan sepanjang periode 2013-2016
\end{abstract}

Kata Kunci: kinerja, posisi keuangan, Badan Layanan Umum, pendidikan 


\section{PENDAHULUAN}

\section{Latar Belakang Penelitian}

Badan Layanan Umum (BLU) adalah instansi di lingkungan pemerintah yang dibentuk untuk memberikan pelayanan kepada masyarakat berupa penyediaan barang dan/atau jasa yang dijual tanpa mengutamakan mencari keuntungan dan dalam melakukan kegiatannya didasarkan pada prinsip efisiensi dan produktivitas. BLU bertujuan untuk meningkatkan pelayanan kepada masyarakat dalam rangka memajukan kesejahteraan umum dan mencerdaskan kehidupan bangsa dengan memberikan fleksibilitas dalam pengelolaan keuangan berdasarkan prinsip ekonomi dan produktivitas, penerapan praktek bisnis yang sehat (Rahajaan, 2014).

Pola Pengelolaan Keuangan

(PPK) BLU merupakan pola pengelolaan keuangan pada organisasi/instansi pelayanan publik (public service agency) yang memberikan fleksibilitas berupa keleluasaan untuk menerapkan praktek-praktek bisnis yang sehat untuk meningkatkan pelayanan kepada masyarakat. Pola baru ini diharapkan menjadi contoh konkrit dari penerapan manajemen keuangan berbasis pada hasil. Tujuan dibentuknya organisasi penyelenggara pelayanan publik menjadi Badan Layanan Umum (BLU) adalah peningkatan kinerja pelayanan publik menjadi lebih baik. Perubahan status menjadi BLU diharapkan dapat memperbaiki kinerja penyelenggara pelayanan publik, khususnya dalam hal pengelolaan keuangan.

Dalam pelaksanaannya, upaya peningkatan layanan kepada masyarakat saat ini masih belum maksimal dan terdapat beberapa permasalahan yang terkait dengan administrasi pengelolaan keuangan BLU (Waluyo, 2014). Maharani (2013) melakukan penelitian pada BLU Universitas Sebelas Maret. Hasilnya menunjukkan bahwa kinerja keuangan dan pelayanan Universitas Sebelas Maret Surakarta cenderung meningkat dan lebih baik. Penelitian Andi dan Trisnantoro (2014), Studi Kasus RSUD BLUD DR. H.M. Rabain Kabupaten Muara Enim, menyatakan meskipun pengelolaan telah menggunakan konsep BLU dan diawasi oleh badan pengawas, namun belum terlihat peningkatan kinerja rumah sakit secara signifikan. Rosyadi, dkk (2011) melakukan penelitian tentang kinerja keuangan RSUD Sawahlunto menyatakan bahwa secara keseluruhan evaluasi dari sisi posisi keuangan RSUD Sawahlunto memberikan hasil cukup baik, namun jika dilihat dari sisi kinerja/aktivitas menunjukkan bhwa kinerja RSUD Sawahlunto belum baik karena pendapatan RSUD belum mampu menutupi seluruh pembiayaan operasionalnya (defisit).

Berdasarkan uraian di atas, bisa disimpulkan terdapat hasil penelitian yang relatif berbeda satu sama lain. Selain itu penelitian terdahulu di atas dilakukan pada satu unit satuan kerja tunggal pada periode dan waktu yang berbeda. Oleh karena itu penelitian ini dilakukan untuk melihat bagaimana aktivitas/kinerja dan kondisi keuangan beserta perkembangannya pada sejumlah BLU yang ada di Indonesia pada periode yang sama. Penelitian ini difokuskan pada BLU yang memberikan layanan penyediaan barang/jasa, terdiri dari 126 satuan kerja yang bergerak dalam lingkungan rumah sakit (41 satuan kerja), perguruan tinggi (68 satuan kerja), serta balai laboratorium, pengujian, dan lainnya (17 satuan kerja), selama kurun waktu 3 tahun terakhir. 
Yuliana sari.,dkk, Analisis Komparasi atas Kinerja dan Keuangan Badan...

\section{TINJAUAN PUSTAKA \\ Laporan Keuangan}

Laporan keuangan adalah hasil akhir dari proses akuntansi. Menurut Warren, dkk. (2015) laporan posisi keuangan (statement of financial position) adalah daftar aset, libilitas, dan ekuitas pemilik pada waktu tertentu, biasanya pada tanggal terakhir dari bulan atau tahun tertentu. Sedangkan laporan aktivitas adalah bentuk laporan laba rugi (income statements) bagi badan/instansi pemerintahan. Jika merujuk definisi laporan laba rugi (Warren, dkk, 2015) adalah ringkasan dari pendapatan dan beban untuk suatu periode tertentu, seperti satu bulan atau satu tahun. Demikian laporan aktivitas sesungguh adalah laporan yang menunjukkan kegiatan badan dalam menjalankan an usahanya dalam rangka menperoleh pendapatan serta beban-beban yang dikeluarkan dalam rangka menghasilkan pendapat tersebut.

\section{Tujuan dan Manfaat Laporan Keuangan}

Laporan keuangan disusun dalam rangka menyediakan informasi yang berkaitan dengan kinerja maupun posisi keuangan suatu perusahaan. Informasi ini selanjutnya menjadi dasar bagi pengguna laporan keuangan untuk melakukan pengambilan keputusan ekonomi. Laporan keuangan juga merupakan pertanggungjawaban manajemen perusahaan atas pengelolaan perusahaan serta sumberdaya yang dimiliki perusahaan.

\section{Badan Layanan Umum (BLU)}

Badan Layanan Umum (BLU)

adalah instansi di lingkungan Pemerintah yang dibentuk untuk memberikan pelayanan kepada masyarakat berupa penyediaan barang dan/atau jasa yang dijual tanpa mengutamakan mencari keuntungan dan dalam melakukan kegiatannya didasarkan pada prinsip efisiensi dan produktifitas. BLU merupakan instansi pemerintah yang diberikan mandat oleh Kementerian/Lembaga untuk menyelenggarakan layanan publik, seperti layanan kesehatan, pendidikan, pengelolaan kawasan dan pengelolaan dana (Waluyo, 2014)

\section{Badan Layanan Umum}

Menurut Lukman (2013), terdapat karakteristik khusus yang membedakan antara Badan Layanan Umum dengan unit organisasi atau institusi pemerintah lainnya. Karakteristik dimaksud, yaitu:

1. BLU memberikan layanan langsung bagi masyarakat. Pendapatan yang diperoleh oleh BLU diperoleh dari masyarakat sebagai konsumennya, yang merupakan penghasilan. berbentuk Penerimaan Bukan Pajak/PNBP

2. BLU harus menjalankan praktik bisnis sebagaimana sector privat, namun tanpa mengutamakan pencarian keuntungan.

3. BLU dijalankan dengan prinsip efisien dan produktivitas. Berbeda dari instansi pemerintah yang dalam penyelenggaraan layanannya mengedepankan kepada penyerapan anggaran yang sangat tinggi, maka pada BLU penyerapan anggaran bukanlah target karena surplus/kelebihan anggaran dapat digunakan kembali pada tahun berikutnya untuk peningkatan kualitas layanannya.

4. Adanya fleksibilitas dan otonomi dalam menjalankan operasional BLU, yaitu fleksibilitas dalam pengelolaan keuangan, dalam 
pengelolaan sumber daya manusia dan dalam pengelolaan dan pengadaan aset.

5. BLU dikecualikan dari ketentuan pengelolaan keuangan negara pada umumnya. Ketentuan ini merupakan semangat otonomi yang diberikan kepada BLU untuk "bisa melanggar" ketentuan dalam keuangan negara. Contohnya adalah BLU diperkenankan untuk menggunakan secara langsung penerimaannya (PNBP bagi BLU Pusat atau lain-lain PAD yang sah bagi BLUD).

\section{Jenis dan Jumlah BLU di Indonesia}

Berdasarkan data dari

Direktorat Pembinaan Pengelolaan Keuangan Badan Layanan Umum, Satuan Kerja yang telah ditetapkan untuk menerapkan PK BLU per 10 Juni 2016 jumlahnya 136 satuan kerja (http://kemenkeu.go.id diakses tanggal 10 Juni 2016). Adapun rincian detailnya meliputi :

a) BLU Pelayanan Penyediaan Barang/Jasa (126 satuan kerja)

BLU ini memberikan penyediaan barang/jasa dibawah pengelolaan Kementerian (10 satuan kerja); Badan (1 satuan kerja); dan Lembaga (2 satuan kerja. Jika dilihat dari lingkup pekerjaan, BLU layanan penyediaan barang/jasa ini bergerak di bidang kesehatan (rumah sakit), pendidikan (perguruan tinggi), serta laboratorium/pengujian dan lainnya.

b) BLU Pelayanan Pengelolaan Wilayah/Kawasan (4 satuan kerja) BLU ini dibawah pengelolaan/ kewenangan Sekretariat Negara (2 satuan kerja) dan Badan (2 satuan kerja) c) BLU Pelayanan Pengelolaan Dana Khusus (6 satuan kerja)

BLU ini dibawah pengelolaan/ kewenangan Kementerian (6 satuan kerja)

\section{METODE PENELITIAN}

Objek dalam penelitian ini adalah laporan aktivitas (kinerja) dan laporan posisi keuangan Badan layanan Umum (BLU) periode 2013-2016 di lingkungan pemerintah Pusat, khususnya BLU di bidang pelayanan/penyediaan jasa pendidikan. Populasi dalam penelitian ini adalah Badan Layanan Umum yang berjumlah 136 satuan kerja dan berada dibawah pengelolaan/kewenangan kementerian /badan/lembaga negara. Dari jumlah tersebut BLU diklasifikasikan dalam 3 jenis layanan, yaitu: 1) Layanan penyediaan barang dan jasa; 2) layanan pengelolaan wilayah/kawasan; dan 3) layanan pengelolaan dana khusus. BLU bidang penyediaan barang dan jasa memberikan layanan dalam bentuk layanan kesehatan (rumah sakit), pendidikan (perguruan tinggi), dan balai laboratorium/kajian lainnya dengan jumlah keseluruhan BLU sebanyak 126 satuan kerja. Pemilihan sampel dilakukan secara Judgment Sampling dengan kriteria yaitu BLU yang memberikan layanan penyediaan barang dan jasa bidang pendidikan. Dengan demikian sampel penelitian ini adalah semua perguruan tinggi BLU yang berjumlah $\mathbf{3 3}$ satuan kerja.

Data yang digunakan adalah sekunder, yang didapatkan baik dari Laporan Keuangan Pemerintah Pusat (LKPP). Penelitian ini dilakukan untuk mendapatkan gambaran perkembangan kinerja dan posisi keuangan (aset dan kewajiban) perguruan tinggi BLU yang ada di Indonesia periode 2013-2016 
Yuliana sari.,dkk, Analisis Komparasi atas Kinerja dan Keuangan Badan...

serta mengetahui perbedaan kinerja dan posisi keuangan antar-perguruan tinggi tersebut. Analisis yang digunakan dalam penelitian ini adalah 1) analisis deskriptif eksploratif, dan 2) uji komparatif menggunakan Analysis of Variance (ANOVA). Teknik analisis deskriptif merupakan teknik yang digunakan untuk mendapatkan profil atau potret atas apa yang ingin diketahui, dan merupakan cara menganalisis dalam penelitian awal sebelum dilakukan penelitian lanjutan. Teknik ini relatif sangat sederhana dan tidak mengukur atau melihat hubungan kausalitas antarvariabel. Untuk memudahkan pemahaman atas hasil yang diperoleh, hasil penelitian kemudian disajikan dalam bentuk grafik atau tabel. Dengan demikian pola-pola tertentu atau trend-tren atas apa yang diteliti akan tergambar dengan jelas. Teknik Analysis of Variance (ANOVA) digunakan untuk menguji perbedaan atau membandingkan variabel yang diuji antar dua kelompok atau lebih. Dengan demikian pada penelitian ini akan dibandingkan kinerja dan posisi keuangan antar-BLU.

\section{HASIL DAN PEMBAHASAN}

Berikut adalah jumlah Badan Layanan Umum (BLU) bidang layanan pendidikan di Indonesia tahun 20132016.

Tabel 4.1 Profil BLU Perguruan Tinggi di Indonesia Tahun 2013-2016

\begin{tabular}{|c|c|c|c|}
\hline \multirow{2}{*}{ Tahun } & \multicolumn{2}{|c|}{ Jumlah } & \multirow{2}{*}{ Keterangan } \\
\cline { 2 - 3 } & Terdaftar & Ada Data* & \multirow{3}{*}{ Lap. Aktivitas } \\
\hline 2013 & 33 & 31 & \\
\hline 2014 & 33 & 33 & \\
\hline 2015 & 26 & 22 & \multirow{3}{*}{ Neraca } \\
\hline 2016 & 28 & 28 & \\
\hline & & 32 & \\
\hline 2013 & 33 & 33 & 22 \\
\hline 2014 & 33 & 28 & \multirow{2}{*}{} \\
\hline 2015 & 26 & 28 &
\end{tabular}

Dari data di atas dapat dilihat bahwa jumlah BLU Perguruan Tinggi periode 2013 sampai 2016 berfluktuasi. Hal ini dikarenakan pada tahun tertentu, yaitu 2015 dan 2016 terdapat BLU Perguruan Tinggi yang data Laporan
Keuangannya tidak terdapat dalam Laporan Keuangan Pemerintah Pusat (audited). Tidak tersajinya Laporan Keuangan BLU dimaksud disebabkan antara lain belum selesainya proses audit terhadap BLU tersebut.

Tabel 4.2 Perkembangan Posisi Keuangan BLU Perguruan Tinggi Periode 2013-2016

\begin{tabular}{|l|c|c|c|c|c|}
\hline Posisi Keuangan & $\mathbf{2 0 1 3}$ & $\mathbf{2 0 1 4}$ & $\mathbf{2 0 1 5}$ & \multicolumn{1}{c|}{$\mathbf{2 0 1 6}$} & \multicolumn{1}{c|}{ Average } \\
\hline Jumlah Aset & $63,779,085,063,974$ & $66,031,904,018,035$ & $57,684,984,787,523$ & $61,143,525,146,280$ & $62,159,874,753,953$ \\
\hline Jumlah Kewajiban & $1,318,416,837,121$ & $1,546,751,466,888$ & $1,486,102,334,418$ & $1,572,377,542,411$ & $1,480,912,045,210$ \\
\hline Jumlah Ekuitas & $62,460,668,226,853$ & $64,485,152,551,147$ & $56,198,882,453,166$ & $59,571,142,603,867$ & $60,678,961,458,758$ \\
\hline
\end{tabular}

Dari data di atas dapat dilihat bahwa jumlah asset dan kewajiban BLU perguruan tinggi yang menjadi sample pada penelitian ini mengalami fluktuasi khususnya pada tahun 2015, namun ekuitas sepanjang tahun 2013-2016 terus 
mengalami peningkatan, sebagaimana dapat juga dilihat dari grafik berikut.

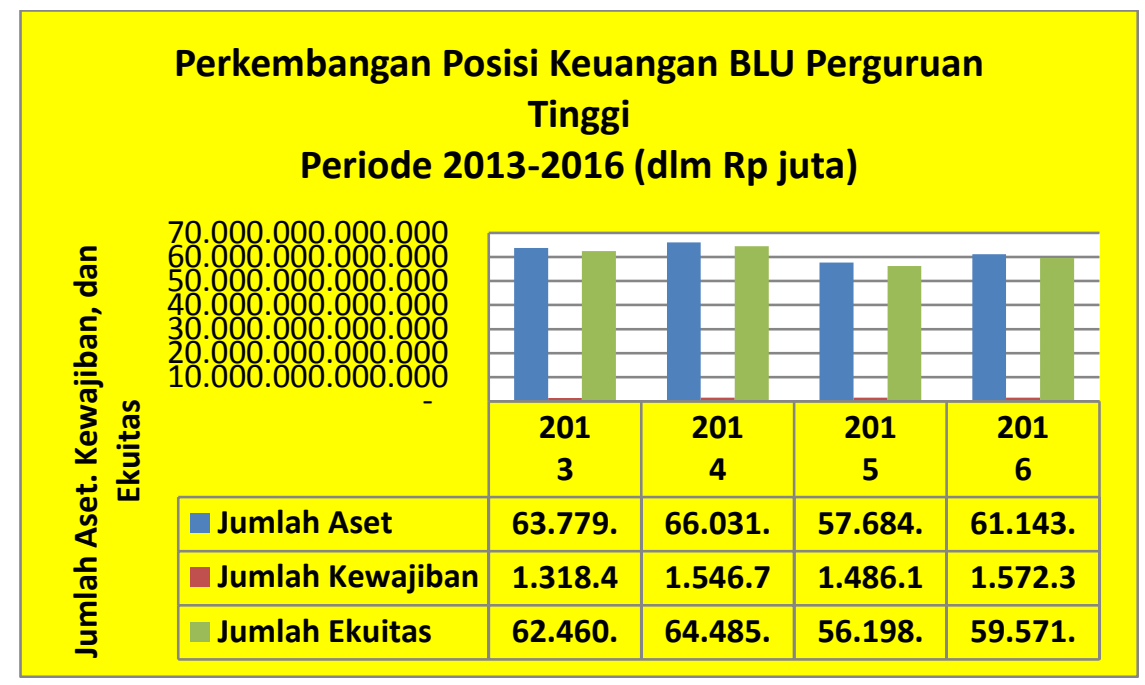

Gambar 4.1 Grafik Perkembangan Posisi Keuangan BLU perguruan Tinggi Periode 2013-2016

Berikut adalah perkembangan Aset dari 28 (dua puluh delapan BLU perguruan tinggi periode 2013-2016.

Tabel 4.3 Perkembangan Aset 28 (Dua Puluh Delapan) BLU Perguruan Tinggi Periode 2013-2016

\begin{tabular}{|c|c|c|c|c|c|c|}
\hline \multirow{2}{*}{ No } & \multirow{2}{*}{ Perguruan Tinggi } & \multicolumn{4}{|c|}{ JUMLAH ASET } & \multirow{2}{*}{ Rata-rata } \\
\hline & & 2013 & 2014 & 2015 & 2016 & \\
\hline 1 & Universitas Diponegoro Semarang & $2,738,928,037,617$ & $2,912,585,687,611$ & $2,975,769,985,691$ & $3,132,936,893,612$ & $2,940,055,151,133$ \\
\hline 2 & Universitas Padjadjaran Bandung & $2,347,968,485,911$ & $2,594,073,596,634$ & $2,621,695,455,709$ & $2,752,422,056,406$ & $2,579,039,898,665$ \\
\hline 3 & Universitas Negeri Malang & $942,898,022,932$ & $1,067,278,101,211$ & $1,100,519,790,803$ & $1,349,466,598,295$ & $1,115,040,628,310$ \\
\hline 4 & Universitas Hasanuddin & $3,343,027,912,699$ & $3,676,541,944,907$ & $3,761,856,175,726$ & $3,729,751,836,528$ & $3,627,794,467,465$ \\
\hline 5 & Universitas Brawijaya Malang & $3,588,182,136,366$ & $3,875,047,613,454$ & $3,863,341,340,218$ & $4,369,774,023,425$ & $3,924,086,278,366$ \\
\hline 6 & Universitas Negeri Semarang & $1,112,290,680,826$ & $1,264,387,388,182$ & $1,545,092,202,319$ & $1,794,983,713,620$ & $1,429,188,496,237$ \\
\hline 7 & Universitas Negeri Surabaya & $2,030,104,760,535$ & $2,141,608,788,476$ & $2,304,475,177,815$ & $2,319,898,038,485$ & $2,199,021,691,328$ \\
\hline 8 & Universitas Sebelas Maret Surakarta & $2,493,657,728,353$ & $2,587,793,056,087$ & $2,807,074,000,516$ & $3,373,451,486,615$ & $2,815,494,067,893$ \\
\hline 9 & Institut Teknologi Sepuluh Nopember Surabaya & $2,207,609,767,611$ & $2,315,360,573,994$ & $2,350,740,230,205$ & $2,438,973,866,409$ & $2,328,171,109,555$ \\
\hline 10 & Universitas Lampung & $894,457,208,589$ & $825,480,013,186$ & $995,247,556,558$ & $925,583,371,819$ & $910,192,037,538$ \\
\hline 11 & Universitas Negeri Yogyakarta & $2,019,093,312,480$ & $2,058,217,423,800$ & $2,123,223,630,272$ & $2,105,715,820,614$ & $2,076,562,546,792$ \\
\hline 12 & Universitas Negeri Gorontalo & $516,103,660,456$ & $577,057,317,905$ & $656,413,735,390$ & $603,033,094,769$ & $588,151,952,130$ \\
\hline 13 & Universitas Sriwijaya & $2,577,610,595,876$ & $2,634,092,017,918$ & $2,712,269,469,029$ & $2,764,733,565,359$ & $2,672,176,412,046$ \\
\hline 14 & Universitas Andalas & $2,027,405,368,182$ & $2,165,053,275,146$ & $2,373,662,744,179$ & $2,499,490,412,097$ & $2,266,402,949,901$ \\
\hline 15 & Universitas Jenderal Soedirman Purwokerto & $1,927,533,057,143$ & $1,952,928,448,671$ & $1,998,017,576,351$ & $1,991,419,778,564$ & $1,967,474,715,182$ \\
\hline 16 & Universitas Riau & $868,404,727,838$ & $866,343,187,234$ & $930,635,055,121$ & $981,369,200,725$ & $911,688,042,730$ \\
\hline 17 & Universitas Terbuka & $2,120,353,598,035$ & $2,447,229,371,014$ & $2,772,028,393,605$ & $3,112,390,135,270$ & $2,613,000,374,481$ \\
\hline 18 & Universitas Udayana Denpasar & $2,117,524,639,860$ & $2,164,241,065,693$ & $2,322,224,541,891$ & $2,311,533,280,297$ & $2,228,880,881,935$ \\
\hline 19 & Universitas Gajah Mada & $9,300,528,897,460$ & $8,474,584,308,914$ & $3,183,855,267,684$ & $3,574,244,018,566$ & $6,133,303,123,156$ \\
\hline 20 & Universitas Airlangga & $1,617,989,691,656$ & $1,704,267,520,674$ & $1,849,976,846,005$ & $1,997,528,594,211$ & $1,792,440,663,137$ \\
\hline 21 & Universitas Indonesia & $8,823,212,340,642$ & $9,220,483,148,233$ & $3,946,085,835,556$ & $4,093,157,674,912$ & $6,520,734,749,836$ \\
\hline 22 & Universitas Sumatera Utara & $3,270,282,872,454$ & $3,442,160,449,835$ & $2,141,391,781,157$ & $2,155,776,254,963$ & $2,752,402,839,602$ \\
\hline 23 & Institut Teknologi Bandung & $1,483,196,058,950$ & $1,635,116,427,192$ & $1,829,338,000,000$ & $2,122,196,000,000$ & $1,767,461,621,536$ \\
\hline 24 & Institut Pertanian Bogor & $1,031,591,442,284$ & $736,836,569,866$ & $1,303,089,612,828$ & $1,443,770,339,493$ & $1,128,821,991,118$ \\
\hline 25 & Universitas Mataram & $778,658,333,052$ & $899,184,832,765$ & $1,055,852,133,988$ & $1,111,624,424,709$ & $961,329,931,129$ \\
\hline 26 & Universitas Tadulako & $833,403,656,763$ & $948,127,175,042$ & $1,121,386,420,605$ & $1,021,438,659,988$ & $981,088,978,100$ \\
\hline 27 & Politeknik Negeri Malang & $621,372,215,688$ & $682,470,888,377$ & $808,293,820,423$ & $801,172,569,308$ & $728,327,373,449$ \\
\hline 28 & Universitas SAT Banten & $145,695,853,716$ & $163,353,826,014$ & $231,428,007,879$ & $265,689,437,221$ & $201,541,781,208$ \\
\hline & Jumlah & $63,779,085,063,974$ & $66,031,904,018,035$ & $57,684,984,787,523$ & $61,143,525,146,280$ & $62,159,874,753,953$ \\
\hline
\end{tabular}


Yuliana sari.,dkk, Analisis Komparasi atas Kinerja dan Keuangan Badan...

Dari data di atas perguruan tinggi dengan asset tertinggi adalah Universitas Indonesia, Universitas Gajahmada, dan Universitas Brawijaya. Sedangkan perguruan tinggi dengan asset terendah adalah Universitas SAT Banten, Politeknik Negeri Malang, dan Universitas Negeri Gorontalo.

Tabel 4.4Perkembangan Kewajiban 28 (Dua Puluh Delapan) BLU Perguruan Tinggi Periode 2013-2016

\begin{tabular}{|c|c|c|c|c|c|c|}
\hline \multirow{2}{*}{ No } & \multirow{2}{*}{ Perguruan Tinggi } & \multicolumn{4}{|c|}{ JUMLAH KEWAJIBAN } & \multirow{2}{*}{ Rata-rata } \\
\hline & & 2013 & 2014 & 2015 & 2016 & \\
\hline 1 & Universitas Diponegoro Semarang & $33,568,279,669$ & $130,520,143,559$ & $76,856,727,457$ & $22,985,223,768$ & $65,982,593,613$ \\
\hline 2 & Universitas Padjadjaran Bandung & $62,409,759,329$ & $65,504,744,610$ & $57,541,564,868$ & $64,499,960,486$ & $62,489,007,323$ \\
\hline 3 & Universitas Negeri Malang & $67,904,307,958$ & $92,094,991,738$ & $1,679,871,196$ & $109,109,678,853$ & $67,697,212,436$ \\
\hline 4 & Universitas Hasanuddin & $51,711,685,078$ & $59,124,650,317$ & $80,353,811,116$ & $51,558,879,276$ & $60,687,256,447$ \\
\hline 5 & Universitas Brawijaya Malang & $88,111,186,942$ & $49,278,483,574$ & $10,064,568,340$ & $30,491,880,816$ & $44,486,529,918$ \\
\hline 6 & Universitas Negeri Semarang & $529,293,241$ & $567,614,487$ & $54,054,650,983$ & $42,804,637,049$ & $24,489,048,940$ \\
\hline 7 & Universitas Negeri Surabaya & $52,820,117,490$ & $19,365,155,480$ & $9,657,405,078$ & $32,115,652,946$ & $28,489,582,749$ \\
\hline 8 & Universitas Sebelas Maret Surakarta & $28,957,629,324$ & $32,444,813,842$ & $52,330,356,132$ & $47,778,987,420$ & $40,377,946,680$ \\
\hline 9 & Institut Teknologi Sepuluh Nopember Surabaya & $64,216,022,733$ & $73,170,760,418$ & $48,827,269,590$ & $77,144,673,626$ & $65,839,681,592$ \\
\hline 10 & Universitas Lampung & $14,897,526,544$ & $12,771,341,110$ & $21,919,729,037$ & $30,771,744,572$ & $20,090,085,316$ \\
\hline 11 & Universitas Negeri Yogyakarta & $44,731,436,310$ & $52,498,053,756$ & $52,117,874,606$ & $47,360,371,141$ & $49,176,933,953$ \\
\hline 12 & Universitas Negeri Gorontalo & $3,067,628,061$ & $1,568,170,176$ & $1,097,990,660$ & $19,853,213,121$ & $6,396,750,505$ \\
\hline 13 & Universitas Sriwijaya & $51,864,731,775$ & $39,489,027,246$ & $14,701,177,805$ & $22,031,891,219$ & $32,021,707,011$ \\
\hline 14 & Universitas Andalas & $39,414,370,745$ & $21,269,149,775$ & $21,565,639,978$ & $23,253,873,972$ & $26,375,758,618$ \\
\hline 15 & Universitas Jenderal Soedirman Purwokerto & $27,086,059,359$ & $26,728,982,174$ & $25,498,884,512$ & $34,000,830,849$ & $28,328,689,224$ \\
\hline 16 & Universitas Riau & $20,112,209,518$ & $30,504,588,072$ & $38,382,542,202$ & $53,272,218,220$ & $35,567,889,503$ \\
\hline 17 & Universitas Terbuka & $21,077,830,258$ & $22,836,519,153$ & $12,902,139,329$ & $9,189,348,268$ & $16,501,459,252$ \\
\hline 18 & Universitas Udayana Denpasar & $26,838,989,938$ & $14,678,171,819$ & $62,984,084,779$ & $58,565,080,586$ & $40,766,581,781$ \\
\hline 19 & Universitas Gajah Mada & $212,669,311,881$ & $104,423,765,806$ & $115,761,868,518$ & $84,007,624,964$ & $129,215,642,792$ \\
\hline 20 & Universitas Airlangga & $40,541,954,784$ & $58,235,343,688$ & $76,828,680,175$ & $68,557,620,038$ & $61,040,899,671$ \\
\hline 21 & Universitas Indonesia & $124,077,226,637$ & $195,436,195,767$ & $231,955,523,169$ & $199,853,048,934$ & $187,830,498,627$ \\
\hline 22 & Universitas Sumatera Utara & $25,190,919,402$ & $53,676,341,467$ & $79,855,403,863$ & 78,147,047,497 & $59,217,428,057$ \\
\hline 23 & Institut Teknologi Bandung & $61,420,749,213$ & $181,545,281,510$ & $144,229,000,000$ & $151,734,000,000$ & $134,732,257,681$ \\
\hline 24 & Institut Pertanian Bogor & $108,164,009,886$ & $133,354,508,016$ & $88,376,874,069$ & $77,212,501,991$ & $101,776,973,491$ \\
\hline 25 & Universitas Mataram & $17,539,055,143$ & $37,891,648,536$ & $52,468,739,171$ & $81,618,839,982$ & $47,379,570,708$ \\
\hline 26 & Universitas Tadulako & $19,344,630,009$ & $25,710,827,699$ & $36,976,526,801$ & $38,967,252,313$ & $30,249,809,206$ \\
\hline 27 & Politeknik Negeri Malang & 184,563 & $11,897,693,093$ & $16,230,984,542$ & $14,918,716,564$ & $10,761,894,691$ \\
\hline 28 & Universitas SAT Banten & $10,149,731,331$ & $164,500,000$ & $882,446,442$ & $572,743,940$ & $2,942,355,428$ \\
\hline & Jumlah & $1,318,416,837,121$ & $1,546,751,466,888$ & $1,486,102,334,418$ & $1,572,377,542,411$ & $1,480,912,045,210$ \\
\hline
\end{tabular}

Dilihat dari kewajiban yang dimiliki perguruan tinggi, maka yang memiliki kewajiban terbesar berturut-turut adalah Universitas Indonesia, Institut Teknologi Bandung, dan Universitas Gajah Mada.
Sedangkan perguruan tinggi dengan kewajiban terkecil adalah Universitas SAT Banten, Universitas Negeri Gorontalo, dan Politeknik Negeri Malang 
Journal of Business Administration Vol 3, No 2, September 2019, hlm, 271- 280

Tabel 4.5Perkembangan Ekuitas 28 (Dua Puluh Delapan) BLU Perguruan Tinggi

Periode 2013-2016

\begin{tabular}{|c|c|c|c|c|c|c|}
\hline \multirow{2}{*}{ No } & \multirow{2}{*}{ Perguruan Tinggi } & \multicolumn{4}{|c|}{ JUMLAH EKUITAS } & \multirow{2}{*}{ Rata-rata } \\
\hline & & 2013 & 2014 & 2015 & 2016 & \\
\hline 1 & Universitas Diponegoro Semarang & $2,705,359,757,948$ & $2,782,065,544,052$ & $2,898,913,258,234$ & $3,109,951,669,844$ & $2,874,072,557,520$ \\
\hline 2 & Universitas Padjadjaran Bandung & $2,285,558,726,582$ & $2,528,568,852,024$ & $2,564,153,890,841$ & $2,687,922,095,920$ & $2,516,550,891,342$ \\
\hline 3 & Universitas Negeri Malang & $874,993,714,974$ & $975,183,109,473$ & $1,098,839,919,607$ & $1,240,356,919,442$ & $1,047,343,415,874$ \\
\hline 4 & Universitas Hasanuddin & $3,291,316,227,621$ & $3,617,417,294,590$ & $3,681,502,364,610$ & $3,678,192,957,252$ & $3,567,107,211,018$ \\
\hline 5 & Universitas Brawijaya Malang & $3,500,070,949,424$ & $3,825,769,129,880$ & $3,853,276,771,878$ & $4,339,282,142,609$ & $3,879,599,748,448$ \\
\hline 6 & Universitas Negeri Semarang & $1,111,761,387,585$ & $1,263,819,773,695$ & $1,491,037,551,336$ & $1,752,179,076,571$ & $1,404,699,447,297$ \\
\hline 7 & Universitas Negeri Surabaya & $1,977,284,643,045$ & $2,122,243,632,996$ & $2,294,817,772,737$ & $2,287,777,385,539$ & $2,170,530,858,579$ \\
\hline 8 & Universitas Sebelas Maret Surakarta & $2,464,700,099,029$ & $2,555,348,242,245$ & $2,754,743,644,384$ & $3,325,672,499,195$ & 2,775,116,121,213 \\
\hline 9 & Institut Teknologi Sepuluh Nopember Surabaya & $2,143,393,744,878$ & $2,242,189,813,576$ & $2,301,912,960,615$ & $2,361,829,192,783$ & $2,262,331,427,963$ \\
\hline 10 & Universitas Lampung & $879,559,682,045$ & $812,708,672,076$ & $973,327,827,521$ & $894,811,627,247$ & $890,101,952,222$ \\
\hline 11 & Universitas Negeri Yogyakarta & $1,974,361,876,170$ & $2,005,719,370,044$ & $2,071,105,755,666$ & $2,058,355,449,473$ & $2,027,385,612,838$ \\
\hline 12 & Universitas Negeri Gorontalo & $513,036,032,395$ & $575,489,147,729$ & $655,315,744,730$ & $583,179,881,648$ & $581,755,201,626$ \\
\hline 13 & Universitas Sriwijaya & $2,525,745,864,101$ & $2,594,602,990,672$ & 2,697,568,291,221 & $2,742,701,674,140$ & $2,640,154,705,034$ \\
\hline 14 & Universitas Andalas & $1,987,990,997,437$ & 2,143,784,125,371 & $2,352,097,104,201$ & $2,476,236,538,125$ & $2,240,027,191,284$ \\
\hline 15 & Universitas Jenderal Soedirman Purwokerto & $1,900,446,997,784$ & $1,926,199,466,497$ & $1,972,518,691,839$ & $1,957,418,947,715$ & $1,939,146,025,959$ \\
\hline 16 & Universitas Riau & $848,292,518,320$ & $835,838,599,162$ & $892,252,512,919$ & $928,096,982,505$ & $876,120,153,227$ \\
\hline 17 & Universitas Terbuka & $2,099,275,767,777$ & $2,424,392,851,861$ & $2,759,126,254,275$ & $3,103,200,787,002$ & $2,596,498,915,229$ \\
\hline 18 & Universitas Udayana Denpasar & $2,090,685,649,922$ & $2,149,562,893,874$ & $2,259,240,457,112$ & $2,252,968,199,711$ & 2,188,114,300,155 \\
\hline 19 & Universitas Gajah Mada & $9,087,859,585,579$ & $8,370,160,543,108$ & $3,068,093,399,166$ & $3,490,236,393,601$ & $6,004,087,480,364$ \\
\hline 20 & Universitas Airlangga & $1,577,447,736,872$ & $1,646,032,176,986$ & $1,773,148,165,830$ & $1,928,970,974,173$ & $1,731,399,763,465$ \\
\hline 21 & Universitas Indonesia & $8,699,135,114,005$ & $9,025,046,952,466$ & $3,714,130,312,387$ & $3,893,304,625,978$ & $6,332,904,251,209$ \\
\hline 22 & Universitas Sumatera Utara & $3,245,091,953,052$ & $3,388,484,108,368$ & $2,061,536,377,294$ & $2,077,629,207,466$ & $2,693,185,411,545$ \\
\hline 23 & Institut Teknologi Bandung & $1,421,775,309,737$ & $1,453,571,145,682$ & $1,685,109,000,000$ & $1,970,462,000,000$ & $1,632,729,363,855$ \\
\hline 24 & Institut Pertanian Bogor & $923,427,432,398$ & $603,482,061,850$ & $1,214,712,738,759$ & $1,366,557,837,501$ & $1,027,045,017,627$ \\
\hline 25 & Universitas Mataram & $761,119,277,909$ & $861,293,184,229$ & $1,003,383,394,817$ & $1,030,005,584,727$ & $913,950,360,421$ \\
\hline 26 & Universitas Tadulako & $814,059,026,754$ & $922,416,347,343$ & $1,084,409,893,869$ & $982,471,407,675$ & $950,839,168,910$ \\
\hline 27 & Politeknik Negeri Malang & $621,372,031,125$ & $670,573,195,284$ & $792,062,835,881$ & $786,253,852,744$ & $717,565,478,759$ \\
\hline 28 & Universitas SAT Banten & $135,546,122,385$ & $163,189,326,014$ & $230,545,561,437$ & $265,116,693,281$ & $198,599,425,779$ \\
\hline & Jumlah & $62,460,668,226,853$ & $64,485,152,551,147$ & $56,198,882,453,166$ & $59,571,142,603,867$ & $60,678,961,458,758$ \\
\hline
\end{tabular}

Selanjutnya dilihat dari perkembangan ekuitas, maka rata-rata ekuitas sepanjang periode 2013-2016 dengan rata-rata terbesar adalah Universitas Indonesia, Universitas Gajah Mada, dan Universitas Brawijaya Malang. Sedangkan perguruan tinggi dengan ekuitas terkecil adalah Universitas SAT Banten, Universitas Gorontalo, dan Politeknik Negeri Malang.

Tabel 4.6 Laporan Aktivitas Periode 2013-2016

\begin{tabular}{|c|c|c|c|c|c|c|}
\hline Tahun & Pendapatan & Biaya & L/R Lain2 & Pos LB & \multicolumn{1}{c|}{ Setor ke KN } & Surp/Def \\
\hline 2013 & $20,131,657,283,814$ & $19,473,732,279,082$ & $310,574,062,263$ & $12,496,313,592$ & $1,320,446,833,351$ & $-339,451,452,764$ \\
\hline 2014 & $22,598,173,730,371$ & $18,988,316,687,147$ & $116,192,200,943$ & $7,037,111,305$ & $7,037,111,305$ & $3,733,086,355,472$ \\
\hline 2015 & $10,120,837,419,551$ & $8,278,301,106,085$ & $-148,978,635,788$ & 0 & $-15,876,892,963$ & $1,709,434,570,641$ \\
\hline 2016 & $16,103,060,129,605$ & $14,126,495,937,825$ & $61,547,966,746$ & $2,672,902,798$ & $68,571,483,813$ & $1,972,213,577,511$ \\
\hline
\end{tabular}


Yuliana sari.,dkk, Analisis Komparasi atas Kinerja dan Keuangan Badan...

Laporan aktivitas BLU menunjukkan jumlah pendapatan yang diterima dan belanja yang dikeluarkan oleh BLU, baik pendapatan/belanja operasional maupun non operasional. Pada Tabel 2 Laporan Aktivitas, terlihat bahwa komponen pendapatan dan beban mengalami penurunan pada tahun 2015 dan 2016 dibanding tahun sebelumnya, yaitu 2013 dan 2014. Hal ini karena, sebagaimana dijelaskan sebelumnya bahwa terdapat data laporan keuangan BLU yang tidak dapat disajikan, yang antara lain disebabkan belum selesainya proses audit pada BLU tertentu.

Tabel 4.7 Komponen Pendapatan BLU Periode 2013-2916

\begin{tabular}{|c|c|c|c|c|c|}
\hline \multirow{2}{*}{ Tahun } & \multicolumn{4}{|c|}{ Pendapatan } & \multirow{2}{*}{ Total Pendapatan } \\
\cline { 2 - 5 } & Jasa Layanan & Hibah & APBN & Lainnya & \\
\hline 2013 & $7,975,630,110,431$ & $306,273,287,060$ & $9,649,673,569,519$ & $2,111,676,418,998$ & $20,131,657,283,814$ \\
\hline 2014 & $9,156,555,794,391$ & $221,284,065,743$ & $9,994,728,582,103$ & $3,225,605,288,134$ & $22,598,173,730,371$ \\
\hline 2015 & $4,234,043,093,622$ & $39,361,454,704$ & $5,179,088,222,103$ & $668,344,649,122$ & $10,120,837,419,551$ \\
\hline 2016 & $7,841,349,194,692$ & $68,914,483,880$ & $7,163,407,210,953$ & $1,029,389,240,080$ & $16,103,060,129,605$ \\
\hline
\end{tabular}

Dari Tabel 3 Komponen pendapatan BLU, meskipun BLU memiliki keleluasan dan otonomi untuk mendapatkan penghasilan secara mandiri namun dapat dilihat bahwa pada umumnya bagian pendapatan (subsidi) dari pemerintah pusat masih menunjukkan jumlah yang cukup signifikan, bahkan untuk tahun 20132015 jumlah pendapatan subsidi ini maih lebih besar dari pendapatan jasa layanan BLU perguruan tinggi.

Tabel 4.8 Posisi Keuangan BLU

\begin{tabular}{|c|c|r|r|}
\hline Tahun & Aset & \multicolumn{1}{c|}{ Kewajiban } & \multicolumn{1}{c|}{ Ekuitas } \\
\hline 2013 & $67,433,700,797,151$ & $1,389,939,662,859$ & $66,043,761,134,292$ \\
\hline 2014 & $71,546,945,079,990$ & $1,658,043,562,913$ & $69,888,901,517,077$ \\
\hline 2015 & $43,431,247,444,293$ & $749,094,984,624$ & $42,682,152,459,730$ \\
\hline 2016 & $54,299,344,453,888$ & $1,697,100,798,674$ & $54,043,601,469,323$ \\
\hline
\end{tabular}

Untuk Laporan posisi keuangan BLU, sebagaimana dijelaskan sebelumnya bahwa terdapat data laporan keuangan BLU yang tidak dapat disajikan, yang antara lain disebabkan belum selesainya proses audit pada BLU tertentu. Oleh karena itu pada tahun 2015-2016, komponen asset, kewajiban maupun ekuitas mengalami penurunan yang cukup signifikan.

Tabel 4.9 Komponen Aset BLU Tahun 2013-2016

\begin{tabular}{|c|c|r|r|r|c|}
\hline Tahun & Aset Lancar & \multicolumn{1}{|c|}{ Investasi } & Aset Tetap (NB) & \multicolumn{1}{c|}{ Aset Lainnya } & \multicolumn{1}{c|}{ Total Aset } \\
\hline 2013 & $7,995,073,525,177$ & $93,408,396,060$ & $58,619,816,309,454$ & $725,402,566,460$ & $67,433,700,797,151$ \\
\hline 2014 & $9,918,910,011,843$ & $161,727,797,063$ & $60,352,039,611,775$ & $1,102,761,098,730$ & $71,546,945,079,990$ \\
\hline 2015 & $5,544,536,769,431$ & 0 & $37,763,769,740,065$ & $122,940,934,797$ & $43,431,247,444,293$ \\
\hline 2016 & $6,660,555,391,364$ & 0 & $47,432,140,893,883$ & $206,648,168,641$ & $54,299,344,453,888$ \\
\hline
\end{tabular}

Dari Tabel .9, dapat dilihat bahwa komponen asset terbesar BLU tahun 2013-2016 
adalah berasal dari Aset Tetap. Pada tahun 2013-2014, BLU memiliki asset dalam bentuk Investasi, namun asset investasi tersebut tidak ada lagi. Masih perlu analisis lebih lanjut untuk mengetahui apa yang menyebabkan BLU perguruan tinggi meniadakan/menghilangkan

investasinya, baik investasi jangka pendek maupun jangka panjang, mulai tahun 2015 tersebut.

\section{KESIMPULAN}

Dari hasil penelitian di atas dapat disimpulkan bahwa:

1. Kinerja keuangan BLU perguruan tinggi yang ada di Indonesia pada periode 20132016 terus mengalami peningkatan.

2. Kondisi keuangan BLU perguruan tinggi yang ada di Indonesia juga terus mengalami peningkatan sepanjang periode 2013-2016..

\section{DAFTAR PUSTAKA}

Andi dan Trisnantoro, Laksono. Pelaksanaan Pengawasan Intern Oleh Dewan Pengawas Dalam Rangka Menuju Optimalisasi Kinerja Studi Kasus RSUD BLUD DR. H.M. Rabain Kabupaten Muara Enim. Jurnal Kebijakan Kesehatan Indonesia. Volume 03 No. 01 Maret 2014 Halaman $10-18$

Lukman, Mediya. (2013). Badan Layanan Umum; Dari Birokrasi Menuju Korporasi. Jakarta: Bumi Aksara Publisher

Ikatan Akuntan Indonesia. 2014. Standar Akuntansi Keuangan. Jakarta: Salemba Empat.
Maharani, Anggit. Analisis Kinerja Keuangan Sebelum dan Sesudah Penerapan Pola Pengelolaan Keuangan Badan Layanan Umum. Jupe UNS, Vol. 1, No. 3 Juni, 2013. Hal 1-10

Peraturan Pemerintah (PP) Nomor 23 Tahun 2005 tentang Pengelolaan Keuangan Badan Layanan Umum sebagaimana diperbaharui dengan PP Nomor 74 Tahun 2012

Rahajaan, Tantri; Alimin Maidin; dan Syahrir A. Pasinringi. 2013. Kajian Implementasi Penerapan Badan Layanan Umum Di RSUP Dr. Wahidin Sudiruhusodo Makassar. Bagian Manajemen Rumah Sakit FKM Universitas Hasanuddin. Artikel tidak dipublikasikan.

Rosyadi, Andria Prima; Handayani; dan Doni Saputra. 2011. Artikel Penelitian Evaluasi Kinerja Keuangan RSUD Sawahlunto Setelah Penerapan Pola Pengelolaan Keuangan Badan Layanan Umum Daerah Tahun 2011. Tidak Dipublikasikan.

Waluyo, Budi. Analisis Permasalahan Pada Implementasi Pola Pengelolaan Keuangan Badan Layanan Umum. Jurnal Infoartha Vol. 3/Tahun XII/2014 (27-38)

http://kemenkeu.go.id 